\title{
SULPHATE METABOLISM OF ARTICULAR CARTILAGE AFTER SURGICAL INTERFERENCE WITH THE JOINT
}

\author{
BY \\ G. MEACHIM \\ From the Department of Pathology, University of Sheffield
}

In human osteo-arthritis there is a loss of matrix ground substance in the fibrillated cartilage (Matthews, 1953; Collins and McElligott, 1960). Studies using radioactive sulphate have indicated that the loss of ground substance is accompanied by a reactive increase in the synthesis of sulphated matrix by all but the more superficial chondrocytes in fibrillated areas (Collins and McElligott, 1960; Collins and Meachim, 1961).

In the rabbit, changes in some respects similar to those of human osteo-arthritis have been induced experimentally by light scarification of the femoral articular surface (Meachim, 1963). This procedure was followed by loss of ground substance in the damaged areas and by a reactive increase in sulphated mucopolysaccharide synthesis, especially by the more superficial chondrocytes near the cuts. The situation differed from that seen in human osteo-arthritis in that the reactive response was more transient and in that the superficial chondrocytes now took part in this response.

One obvious objection to experiments involving scarification is the absence of a history of direct trauma to the cartilage in most cases of human osteoarthritis. In the studies now reported an experimental situation has been found in which a local alteration in sulphate metabolism of a cartilage has followed operative procedures not directly injuring it, namely, interference with the opposing articular surface or the insertion into the joint cavity of a piece of cartilage or plastic.

Articular cartilage consists of chondrocytes embedded in an intercellular matrix which contains collagenous fibres and chondromucoprotein ground substance. The structure of chondromucoprotein has recently been reviewed by Anderson (1962). Each chondromucoprotein unit comprises a molecule of non-collagenous protein to which are attached approximately 26 aggregates of the sulphated mucopolysaccharide chondroitin sulphate. A high percentage of the chondroitin sulphate present in hyaline cartilage is linked to non-collagenous protein in this manner; the rest is either free or intimately associated with the fibrous proteins. In addition to chondroitin sulphate, another sulphated mucopolysaccharide, kerato-sulphate, is found in cartilage with increasing age.

There is a perpetual biological turnover of chondromucoprotein ground substance, with a continual synthesis of new chondromucoprotein by the cartilage cells and a continual breakdown of chondromucoprotein in the intercellular matrix (Gross, Mathews, and Dorfman, 1960). Radioisotope studies have shown that there is no difference in the rates of turnover of the protein component and of the sulphated mucopolysaccharide component of the chondromucoprotein complex; thus it seems likely that the entire complex is metabolized as a unit, being synthesized by the chondrocytes and finally broken down after extrusion into the matrix (Gros Mathews, and Dorfman, 1960).

Since one of the components of chondromucoprotein is sulphated, the metabolism of cartilage ground sub? stance can be studied by techniques employing radioactive sulphate $\left({ }^{35} \mathrm{SO}^{4 \prime \prime}\right)$. There is evidence that the ability of cartilage slices to fix radioactive sulphate in vitro depends upon cellular processes concerned in chondroitin sulphate synthesis (Boström and Månsson, 1953; Boyd and Neuman, 1954); quantitative radiochemical assay of sulphate uptake during 4 hours incubation in a suitable medium in vitro can thus be used as a guide to the rate of chondroitin sulphate synthesis by the cells in a cartilage sample (McElligott and Collins, 1960). Alternatively, by suitably timing an in vivo technique, an attempt can be made to determine the effect of a particular experimental procedure on the breakdown of chondromucoprotein ground substance, by estimating loss of radio-isotope from cartilage previously labelled with radio-active sulphate. In the work now reported these two techniques have been utilized to examine cartilage metabolism.

\section{Experimental Plan and Methods}

Adult male and female rabbits of mixed laboratory stock weighing 2 to $3 \mathrm{~kg}$. were used for the various experiments summarized in Table $I$. The operation was performed on one knee joint, the opposite knee serving as a control. The sulphate metabolism of the femoral articular cartilage from the knee subjected to operation was compared with that of its control sample from the opposite joint. Animals 
developing patellar dislocation or showing evidence of joint cavity infection were excluded from the results.

Operative Technique.-The hair over one knee joint, usually the right, was removed with clippers. The rabbit was then anaesthetized with ether. After cleaning the skin with 70 per cent. alcohol, the joint was opened under sterile precautions. An incision was made through skin and underlying tissue, and then into the joint capsule between the lateral margin of the patella and the lateral margin of the patellar groove of the femur.

Experiment 1a; The patella was then rotated medially and a small shaving of cartilage removed by scalpel from its articular surface, the shaving being discarded from the joint.

Experiment $1 b$; The patella, after being rotated medially, was allowed to fall back into its normal position without actually being incised.

Experiments 2a, b, and $c$, and 3; A small piece of cartilage or polytetrafluorethylene tape was inserted into the joint cavity.

At the conclusion of the operation the joint capsule was closed with nylon sutures and the skin with catgut. Finally the skin incision was covered with film from a "Nobecutane" spray. After operation the animals were allowed full freedom of movement within their cages. The surgical procedures selected did not interfere with use or weight-bearing in the operated limbs.

Inserted Material.-Three different types of material were used for insertion into the joint cavity:

Experiment 2a: A small piece of normal patellar articular cartilage taken directly under full sterile precautions from another adult rabbit.

Experiments 2b and 3: A small piece of patellar articular cartilage taken directly under full sterile precautions from another adult rabbit in which the patella concerned had been traumatized 2 weeks previously by removing a cartilage shaving from the articular surface.

Experiment 2c: Polytetrafluorethylene tape cut into a piece of similar size to that of the cartilage inserts (approx. $4 \times 1.5$ $\mathrm{mm}$.). Before use the material was immersed in chloroform overnight and then in ether overnight. The pieces were sterilized by placing them in glass containers and heating to $150^{\circ} \mathrm{C}$. for $2 \mathrm{hrs}$ in a hot air oven.

Preparation of Specimens. - The rabbits were killed by intracardiac Nembutal. Both knee joints were exposed and inspected. Animals showing post-operative dislocation of the patella or evidence of joint cavity infection were excluded from the results, as were animals in which inserted material was found to have escaped from the joint cavity.

Tissue for quantitative radiochemical study was taken from the patellar groove of the femur by carefully stripping articular cartilage from the underlying bone. A cartilage sample thus removed from the joint which had been subjected to operation was processed in parallel with a sample taken from the same site in the contralateral unoperated joint.

Tissue for histological and autoradiographic study was also obtained as required.

\section{Radiochemical methods}

In vitro Quantitative Procedure (Experiments 1 and 2).-This procedure measured the ability of the cartilage samples to fix sulphate during incubation for $4 \mathrm{hrs}$ in vitro in a medium containing sulphate labelled with radioisotope.

The cartilage samples were placed at once in a flask containing radioactive sulphate medium already warmed to $37^{\circ} \mathrm{C}$., and incubated at this temperature for $4 \mathrm{hrs}$ using a water bath fitted with a shaking machine. The

TABLE I

SUMMARY OF EXPERIMENTS

\begin{tabular}{|c|c|c|c|c|c|}
\hline \multicolumn{2}{|c|}{ Experiment } & \multirow{2}{*}{$\begin{array}{c}\text { Operative Procedure } \\
\text { Small shaving removed from patellar surface } \quad . .\end{array}$} & \multirow{2}{*}{ Number of Animals } & \multirow{2}{*}{$\begin{array}{c}\begin{array}{c}\text { Time after Operation } \\
\text { when Killed (wks) }\end{array} \\
4\end{array}$} & \multirow{3}{*}{$\begin{array}{c}\begin{array}{c}\text { Aspect of Metabolism } \\
\text { Studied }\end{array} \\
\begin{array}{c}\text { Cellular uptake of } \\
\text { sulphate in vitro }\end{array}\end{array}$} \\
\hline 1 & $a$ & & & & \\
\hline & $b$ & Joint opened without injuring the cartilage & 19 & 4 & \\
\hline \multirow[t]{3}{*}{2} & $a$ & \begin{tabular}{cccccc}
\multicolumn{3}{c}{ Small piece of normal cartilage inserted into } \\
joint & $\ldots$ & $\ldots$ & $\ldots$ & $\ldots$ & $\ldots$
\end{tabular} & 10 & 2 & \multirow{3}{*}{$\begin{array}{l}\text { Cellular uptake of } \\
\text { sulphate in vitro }\end{array}$} \\
\hline & $b$ & $\begin{array}{l}\text { Small piece of previously traumatized cartilage } \\
\text { inserted into joint }\end{array}$ & 10 & 2 & \\
\hline & $c$ & $\begin{array}{cccc}\text { Small piece of polytetrafluorethylene tape } \\
\text { inserted into joint } & \ldots & \ldots & \ldots\end{array}$ & 14 & 2 & \\
\hline \multicolumn{2}{|c|}{3} & $\begin{array}{l}\text { Small piece of previously traumatized cartilage } \\
\text { inserted into joint } \quad \ldots \quad \ldots \quad \ldots\end{array}$ & 6 & 2 & $\begin{array}{l}\text { Loss of sulphate from } \\
\text { cartilage prelabelled } \\
\text { in vivo }\end{array}$ \\
\hline
\end{tabular}


medium used was a salt solution containing glucose and buffered to $\mathrm{pH} 7 \cdot 3$. To this was added approximately 5 microcuries $(\mu c)$ of ${ }^{35} \mathrm{~S} / \mathrm{ml}$. (supplied as carrier-free sulphate by the Radiochemical Centre, Amersham). Carrier sulphate was also added as $4 \cdot 8 \mathrm{mg}$. sodium sulphate/litre.

After incubation the cartilage samples were dialysed in changes of isotonic sodium sulphate at $4^{\circ} \mathrm{C}$. to remove unbound sulphate. They were then processed by the technique described in detail by McElligott and Collins (1960). The precipitates thus prepared were counted, using a thin mica end-window Geiger-Müller tube. After correcting for background and dead time, the count $/ \mathrm{min} . / \mathrm{mg}$. of dried cartilage was calculated. The radioactivity acquired by the sample from the joint subjected to operation was compared with that acquired by its control sample from the contralateral unoperated knee. A test/control activity ratio above 1.2 was accepted as evidence of increased femoral sulphate uptake in the operated joint.

In vivo Quantitative Procedure (Experiment 3).-This procedure was used to estimate in vivo sulphate loss in femoral cartilage. The cartilage was first labelled by giving the rabbit an intraperitoneal injection of radioactive sulphate. Carrier-free sodium sulphate $\left(\mathrm{Na}_{2}{ }^{35} \mathrm{SO}_{4}\right)$ was injected at a dosage of $2 \mathrm{mc} . / \mathrm{kg}$. body weight. After an interval of 5 days, a small piece of cartilage from another rabbit was then inserted into one knee joint. The rabbits were killed after a further 2 weeks. The radioactivity remaining in the sample of femoral articular cartilage from the operated knee was then compared with that remaining in its control sample from the opposite joint. The samples were processed without dialysis by the same technique as that employed in the in vitro experiments.

\section{Results}

EXPERIMENT 1

Experiment 1a.-In 21 rabbits the femoral articular cartilage was studied 4 weeks after surgical removal of a small shaving from the surface of its opposing patella.
Histology of the patella at the conclusion of the experiment shows that the patellar defect thus made includes the superficial and transitional zones of the articular cartilage together with a variable depth from the deep zone of radially aligned cell columns (Fig. 1). In no instance does the defect reach into bone. An area of partial, or, less often, complete, loss of matrix metachromasia usually extends well into the underlying cartilage beneath the defect, although in most of the specimens a proportion of the cells in this area of matrix change are still rimmed by metachromatic material (Fig. 1). A few small clusters of chondrocytes are sometimes seen adjacent to the margins of the defect.

The ability of the femoral cartilage to fix sulphate in vitro was studied 4 weeks after the operation. The samples were incubated for $4 \mathrm{hrs}$ in a medium containing labelled sulphate. Autoradiographs confirm that sulphate uptake during this incubation time is due to fixation of the ion by the cartilage cells, since autoradiographic blackening from the presence of radioisotope is localized over the chondrocytes (Fig. 2, opposite).

The radioactivity acquired by a sample of femoral cartilage from the operated joint was compared with that acquired by its control sample from the contralateral unoperated knee. The results are shown in Fig. 3 (opposite), which shows that in the majority of animals the cartilage from the joint subjected to operation showed an increased sulphate uptake when compared with its control sample from the opposite knee. The ratio of sulphate uptake in the two cartilages expressed as test/control exceeded $1 \cdot 2$ in sixteen of the 21 rabbits. Increased femoral sulphate uptake 4 weeks after surgical trauma to the patella has previously been reported by Carlson (1957), who measured sulphate uptake in vivo by photometry of autoradiographs, and the present findings are in keeping with his results.

In eleven rabbits the femoral articular cartilages were examined histologically 4 weeks after the operation. A transverse block was taken through the patellar groove of each femur, and the appearances compared in the test and the control joint. In two rabbits the femoral sections

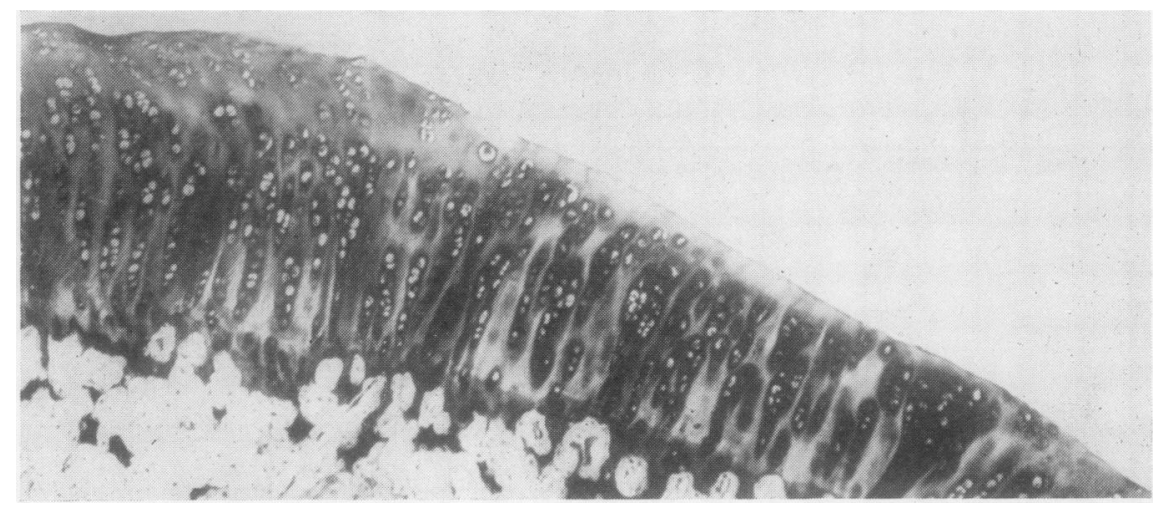

Fig. 1-Patellar cartilage 4 weeks after removal of a small shaving from its articular surface, showing a shallow defect thus made extending into the transitional zone. Note the loss of matrix staining beneath the defect, although many of the deeper cells are still well-rimmed. Toluidine blue. $\times 50$. 


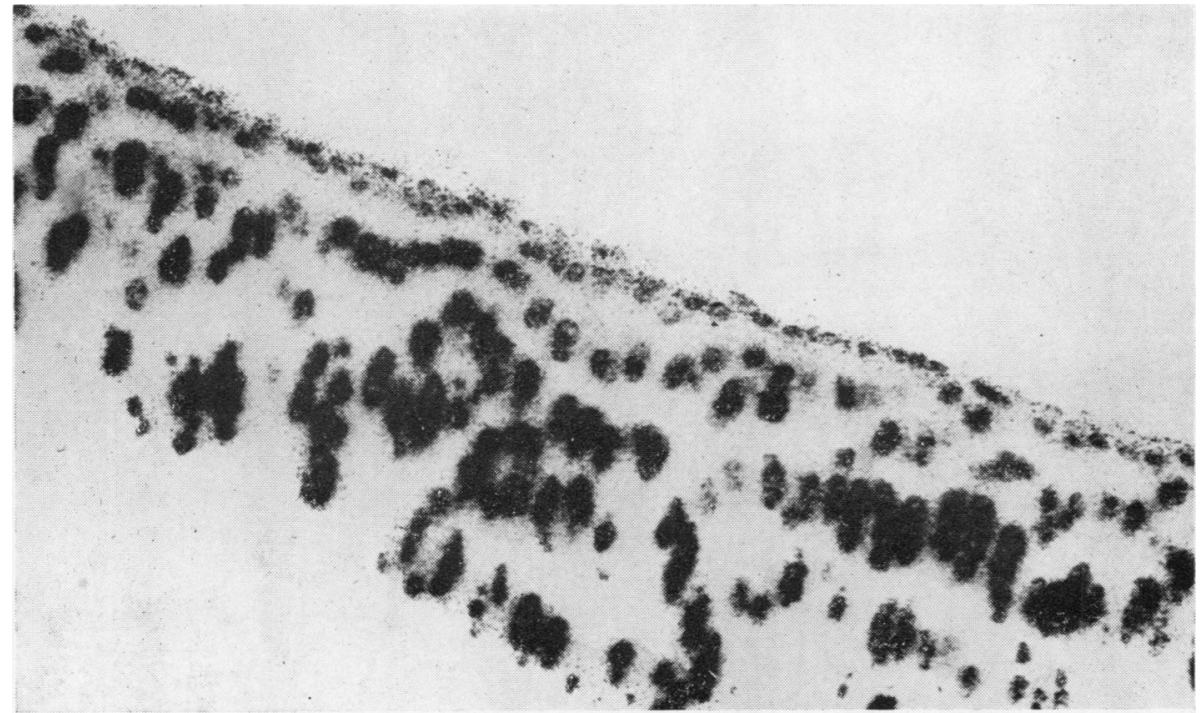

Fig. 2.-Autoradiograph of femoral articular cartilage to show cellular localization of sulphate uptake after 4 hrs' incubation in vitro in a medium containing labelled sulphate. $\times 125$.

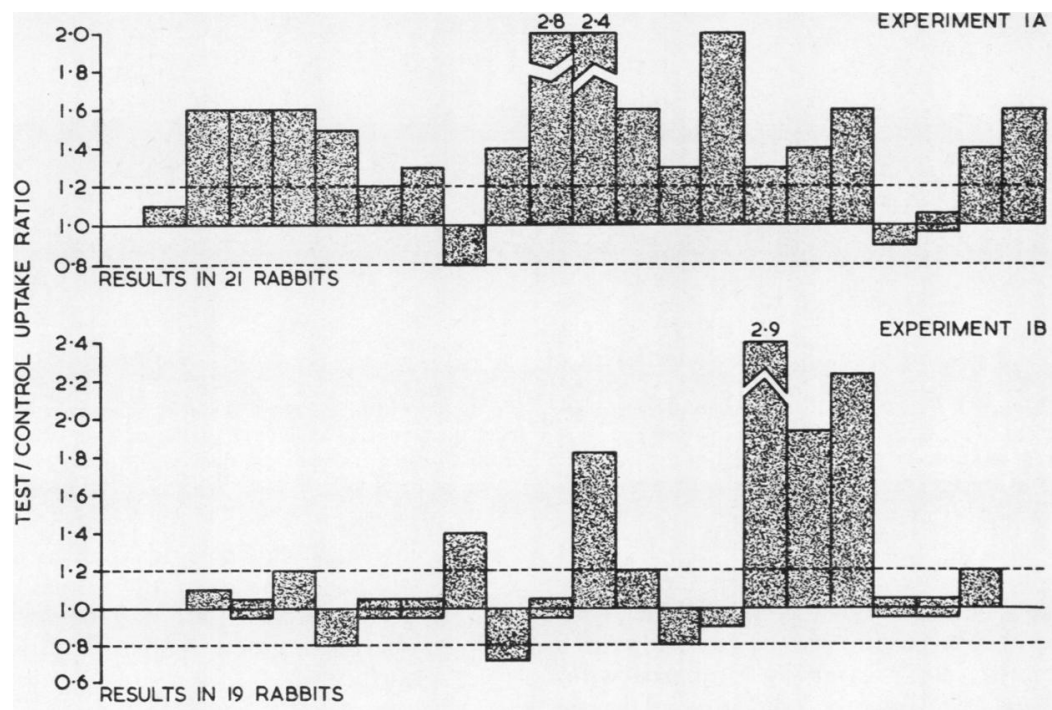

Fig. 3.-Quantitative results of Experiment 1. Sulphate uptake of femoral articular cartilage from the operated knee compared with that of its control sample from the opposite joint. Ratio of uptakes (counts/min./mg. dried cartilage) expressed as test/control.

Experiment 1a: Sulphate uptake in vitro 4 weeks after removing a small shaving from the patellar surface (21).

Experiment $1 b$ : Sulphate uptake in vitro 4 weeks after opening the joint without injuring the cartilage (19).

from the operated knee show a small localized area of superficial fibrillation of the cartilage (Fig. 4, overleaf). In the other nine rabbits, however, no evidence of fibrillation is seen (Fig. 5, overleaf), although on comparison with the control joint there is often a slight reduction in the number of nuclei counted in the superficial zone of the test cartilage. None of the cartilages shows evidence of leucocytic infiltration.

Experiment $1 b$.-In nineteen rabbits the knee joint was 


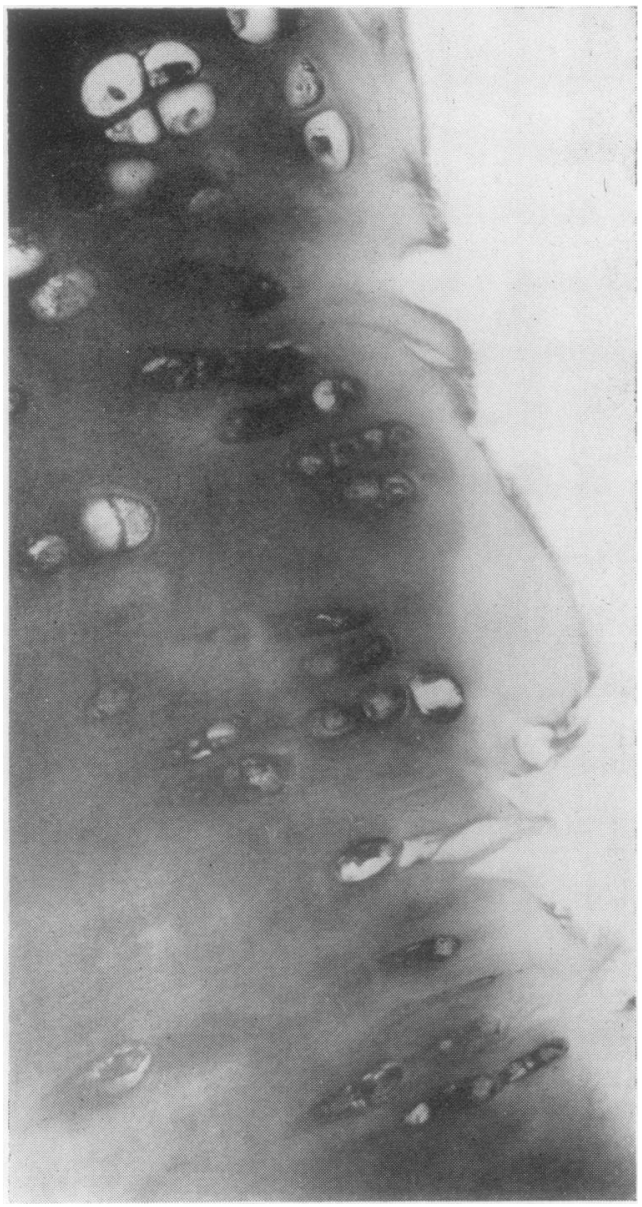

Fig. 4.-A superficial area of fibrillation in the femoral articular cartilage 4 weeks after removing a small shaving from the opposing patella (Experiment 1a). It was unusual to find fibrillation of the femoral surface 4 weeks after this operation, and the appearance was more commonly that illustrated in Fig. 5. Toluidine blue. $\succ \mathbf{3 1 0}$.

opened and then sutured after manipulating the patella without injuring its articular surface; 4 weeks after this procedure sulphate uptake in vitro by the femoral cartilage from the operated joint was again compared with that of its control sample from the contralateral knee. The results are shown in Fig. 3.

It will be seen that increased sulphate uptake above a test/control ratio of $1 \cdot 2$ was now observed in only five of the nineteen rabbits studied. This finding indicates that injury to the patella played a part in causing the altered femoral sulphate metabolism observed in Experiment 1a.

\section{CONCLUSIONS FROM EXPERIMENTS 1A AND 1B}

(1) Damage to one articular surface in a joint can frequently induce an alteration in the metabolism of ground substance in the opposing

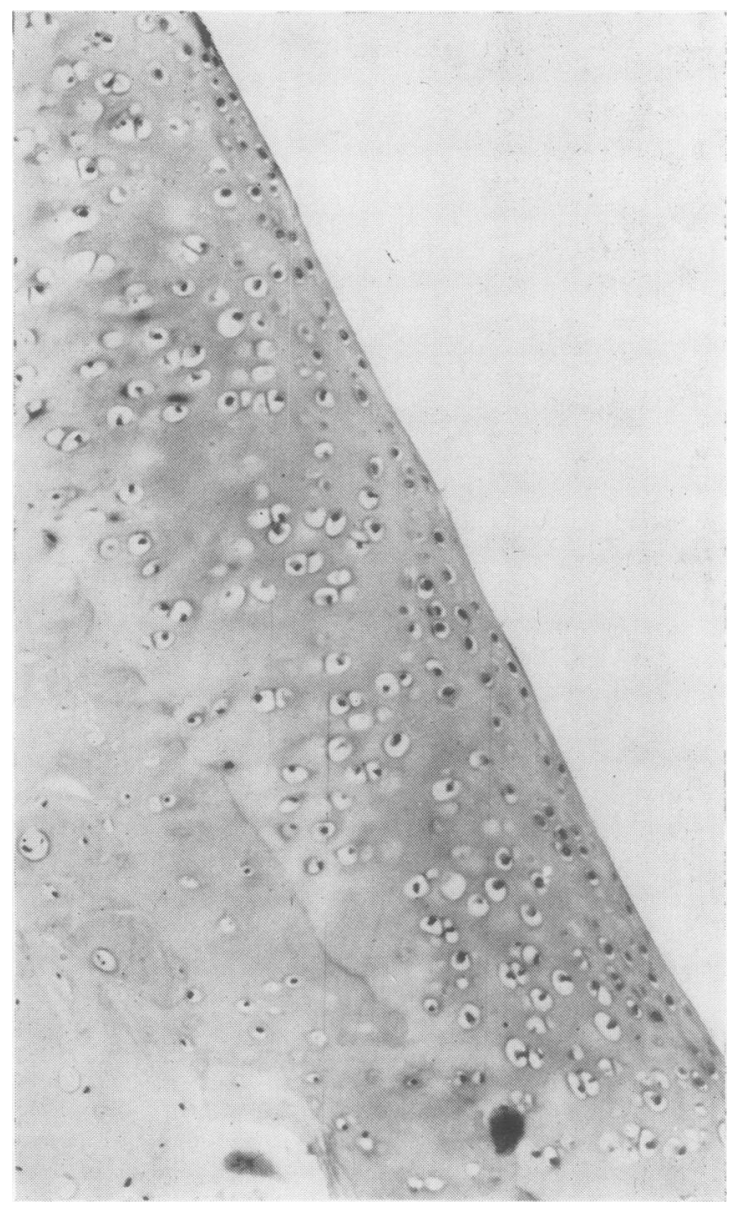

Fig. 5.-Femoral cartilage 4 weeks after removing a small shaving from the opposing patella (Experiment $1 a$ ). There is no evidence of fibrillation of the articular surface. Haematoxylin and eosin. $\times 125$.

articular cartilage, as evidenced by increased cellular utilization of sulphate. Occasionally a similar alteration can be induced merely by opening a joint without injuring the articular surface.

(2) A local alteration in sulphate metabolism can develop in the absence of actual fibrillation of the cartilage concerned.

\section{EXPERIMENT 2}

In 34 rabbits the ability of femoral articular cartilage to fix sulphate in vitro was measured 2 weeks after inserting a small piece of cartilage or plastic into the joint cavity. The radioactivity acquired by femoral cartilage from the operated joint was compared with that acquired 
by its control sample from the contralateral knee. The results are shown in Fig. 6 . Increased femoral sulphate uptake above a test/control ratio of 1.2 was observed in the operated joint of thirteen of the 34 rabbits studied.
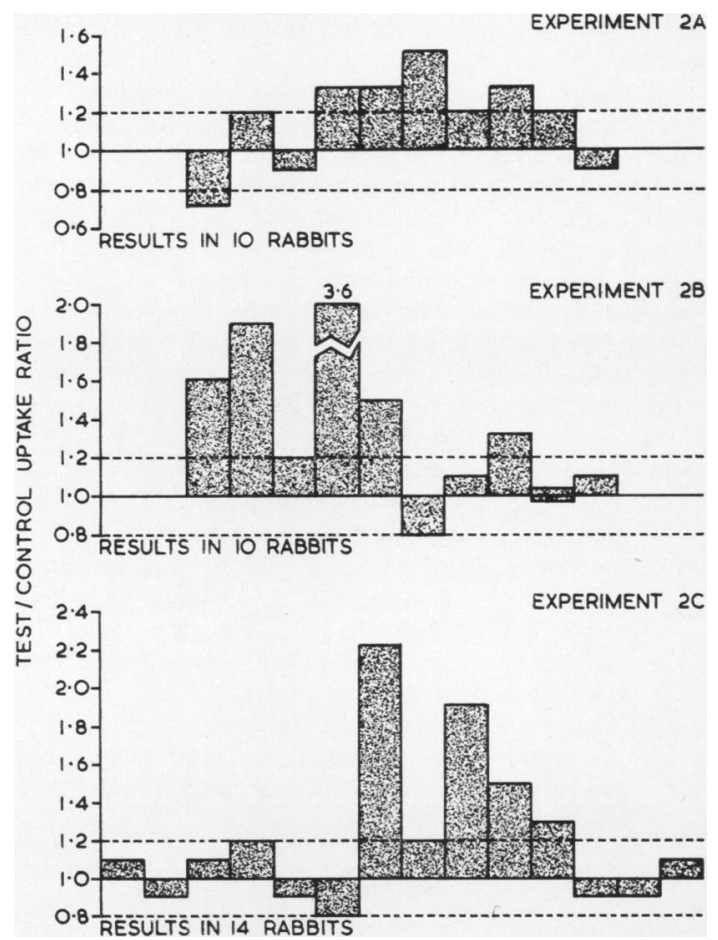

Fig. 6.-Quantitative results of Experiment 2. Sulphate uptake o femoral articular cartilage from the operated knee compared with that of its control sample from the opposite joint. Ratio of uptakes (count/min./mg. dried cartilage) expressed as test/control.

Experiment $2 a$ : Sulphate uptake in vitro 2 weeks after inserting a small piece of normal cartilage into the joint cavity (10).

Experiment $2 b$ : Sulphate uptake in vitro 2 weeks after inserting a small piece of previously traumatized cartilage (10).

Experiment $2 c$ : Sulphate uptake in vitro 2 weeks after inserting a small piece of polytetrafluorethylene tape (14).

Ten animals received a small piece of normal patellar articular cartilage taken directly from other rabbits (Experiment $2 a$ ); ten animals received a small piece of patellar articular cartilage taken directly from other rabbits in which the patella concerned had been traumatized 2 weeks previously by removing a cartilage shaving from the articularsurface(Experiment $2 b$ ); and fourteen animals received a small piece of polytetrafluorethylene tape cut to a similar size to that of the cartilage inserts (Experiment 2c).

The proportion of animals showing increased femoral sulphate uptake was similar in each of these three groups (Fig. 6). Since polytetrafluorethylene is believed to be a chemically inert substance, there was thus no evidence that the effect on sulphate metabolism observed in this experiment was due to a chemical released or activated by the inserted material. It remains unexplained why altered sulphate metabolism was found in only a proportion of the animals studied. Patellar dislocation was excluded as a variable in the experimental situation, and joint cavity infection was not detected in any of the rabbits used.

In fifteen rabbits the femoral articular cartilages were examined histologically 2 weeks after operation. A transverse block was taken through the patellar groove of each femur. The cartilage from the operated joint was compared with its control sample from the contralateral knee. None of the cartilages from the joints receiving inserts shows evidence of fibrillation in the sections examined (Fig. 7). However, in eleven of the fifteen rabbits haematoxylin and eosin staining shows loss of matrix basophilia in the superficial and transitional zones of the femoral cartilage from the operated knee. This finding is often associated with a slight reduction in the number of nuclei counted in the super-

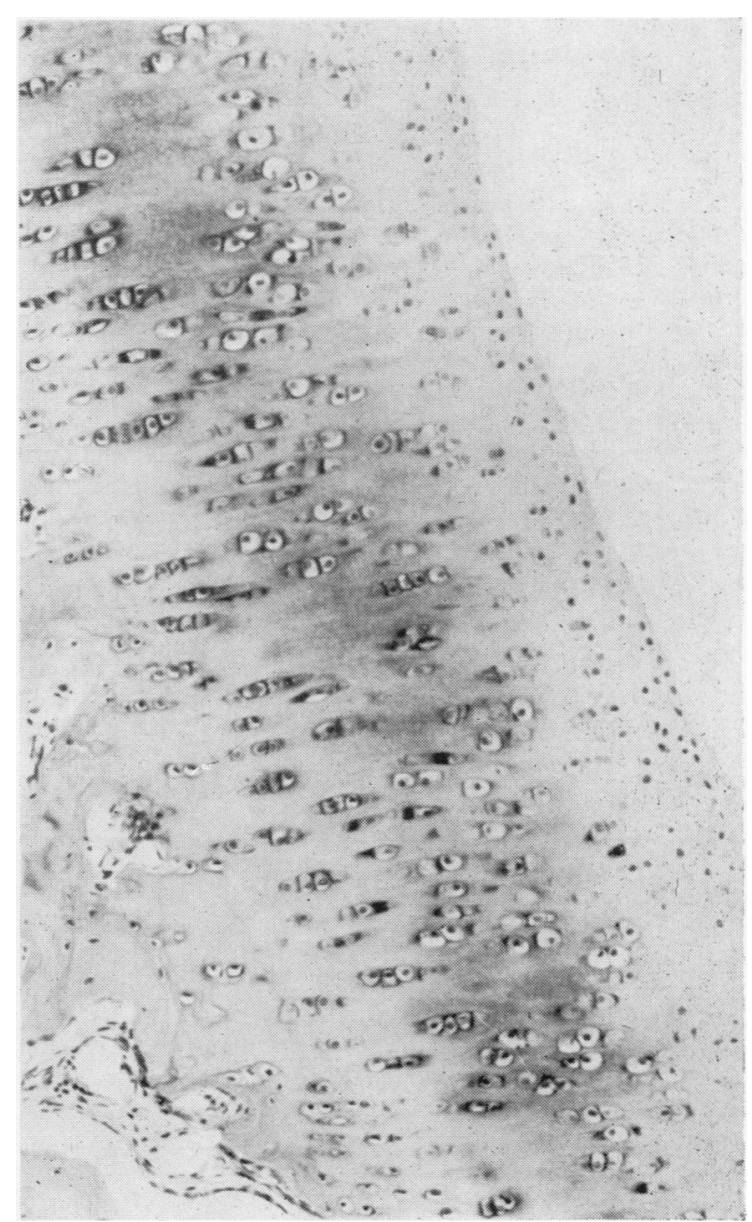

Fig. 7.-Femoral cartilage 2 weeks after inserting a small piece of polytetrafluorethylene tape into the joint cavity (Experiment $2 c$ ). There is no evidence of fibrillation of the articular surface. Haematoxylin and eosin. $\times 125$. 
ficial zone of the test cartilage, and in some cases with a slight apparent reduction in the general intensity of matrix staining with toluidine blue. The proportion of rabbits showing these various changes was similar in those animals showing enhanced cellular uptake of sulphate in vitro and in those animals in which increased sulphate uptake was not detected. None of the sections shows evidence of leucocytic infiltration into the cartilage.

\section{CONCLUSIONS FROM EXPERIMENT 2}

(1) Insertion of a small piece of cartilage or plastic into the cavity of a joint can sometimes induce an alteration in the metabolism of ground substance in its articular cartilage, as evidenced by increased cellular utilization of sulphate.

(2) No evidence was obtained to suggest that this effect is due to a chemical released or activated by the inserted material.

(3) The experiment confirms that a local alteration in sulphate metabolism can develop in the absence of actual fibrillation of the cartilage concerned.

\section{EXPERIMENT 3}

In six rabbits the rate of sulphate loss in vivo was studied in femoral articular cartilage labelled with radioactive sulphate 5 days before inserting a small piece of patellar cartilage into the cavity of one knee joint. The inserted cartilage was taken directly from other adult rabbits in which the patella concerned had been traumatized 2 weeks previously by removing a small shaving from its surface.

Two weeks after inserting this material the radioactivity remaining in the femoral articular cartilage of the operated joint was compared with that remaining in its control femoral sample from the opposite knee. The results are shown in Table II, where radioactive sulphate

TABLE II

QUANTITATIVE RESULTS OF EXPERIMENT 3

Radioactive sulphate $\left({ }^{35} \mathrm{SO}_{4}{ }^{\prime \prime}\right)$ content of rabbit femoral articular cartilage 2 weeks after inserting a small piece of previously traumatized patellar cartilage into the joint cavity, compared with radioactive sulphate content of control femoral cartilage from opposite knee of same rabbit.

\begin{tabular}{|c|c|c|c|}
\hline \multirow{2}{*}{$\begin{array}{l}\text { Rabbit } \\
\text { No. }\end{array}$} & \multicolumn{2}{|c|}{$\begin{array}{c}\text { Radioactive Sulphate Content } \\
\text { of Cartilage }\end{array}$} & \multirow{2}{*}{$\begin{array}{l}\text { Test/Control } \\
\text { Content Ratio }\end{array}$} \\
\hline & Test & Control & \\
\hline $\begin{array}{ll}S & 157 \\
S & 158 \\
S & 159 \\
S & 160 \\
S & 161 \\
S & 162\end{array}$ & $\begin{array}{r}76 \\
154 \\
80 \\
270 \\
76 \\
48\end{array}$ & $\begin{array}{r}118 \\
188 \\
83 \\
243 \\
105 \\
64\end{array}$ & $\begin{array}{l}0.6 \\
0.8 \\
1.0 \\
1 \cdot 1 \\
0.7 \\
0.8\end{array}$ \\
\hline
\end{tabular}

The rabbits were given an intraperitoneal injection of radioactive sulphate ( $2 \mathrm{mc}$. $\mathrm{Na}_{2}{ }^{35} \mathrm{SO}_{4} / \mathrm{kg}$. body weight) 5 days before the operation.

Radioactive sulphate content expressed as radioactivity count $/ \mathrm{min} . / \mathrm{mg}$. of dried cartilage.

Ratio of radioactive sulphate content in the two cartilages expressed as test/control. content is expressed in terms of the radioactivity count min./mg. dried cartilage; the ratio of radiosulphate content is expressed as test/control. It will be seen that sulphate loss in vivo tended to increase in the femoral cartilage of the joint receiving the insert; the ratio of radioactivity was 0.8 or less in four of the six animals studied.

The whole of the femoral groove cartilage was used for the quantitative radiochemical estimation, in order to obtain as large a sample as possible. However, the opportunity was taken to examine the patella by coarse-grain auto-radiography. The distribution of remaining radioactivity suggested that increased sulphate loss had occurred especially in the superficial and transitional zones of the patellar articular cartilage, and on haematoxylin and eosin staining these zones tend to show loss of matrix basophilia in the patella from the test joint. No evidence of patellar fibrillation is seen.

\section{CONCLUSIONS FROM EXPERIMENT 3}

(1) Increased loss of sulphate from the cartilage matrix accompanies the increased cellular utilization of sulphate observed in a proportion of the animals in Experiment 2. Taken together, these findings point to an increased turnover of sulphated ground substance in some of thejoints receiving intra-articular inserts.

(2) The available evidence suggests that the increased loss of sulphated material occurs especially in the superficial and transitional zones of the articular cartilage.

\section{Discussion}

In the experiments described the sulphate metabolism of rabbit femoral articular cartilage has been studied following various operations on the knee joint not involving direct injury to the femoral articular surface. The results indicate that a change in the local environment of an articular cartilage can sometimes affect the metabolsim of its sulphated ground substance. Several possible mechanisms for this phenomenon merit discussion.

One possible explanation is that a chemical substance affecting sulphate metabolsim gains access to the femoral cartilage as a result of post-operative changes in the peri-articular soft tissues. Lack (1961) has shown that local hyperaemia with increased permeability of nearby blood vessels will induce ground substance depletion in the ear cartilage of young rabbits. Various proteolytic enzymes are known to increase loss of chondromucoprotein from cartilage (Curtiss and Klein, 1963), and these enzymes include plasmin, a substance of endogenous origin. Increased loss of matrix chondromucoprotein would be expected to stimulate cellular synthesis of sulphated ground substance, since papain-induced matrix depletion is followed by a reactive increase in sulphate utilization by the cells 
of rabbit cartilage (McElligott and Potter, 1960). It is thus possible that post-operative release or activation of an enzyme by the peri-articular tissues is one factor concerned in the present experiments. This mechanism might account for the altered metabolism observed in a small proportion of rabbits after merely opening the joint without injuring the patella (Experiment $1 \mathrm{~b}$ ), and might also be at least partly responsible for the altered metabolism observed in a proportion of animals after inserting a piece of cartilage or plastic into the joint cavity (Experiment 2).

A change in adjacent non-cartilaginous tissues will not, however, account for the influence of injury to the patella demonstrated in Experiment 1. Here some other mechanism must be involved in altering the sulphate metabolism of the femoral cartilage. One possible explanation is that the traumatized patellar cartilage liberates or activates a chemical substance affecting sulphate metabolism in cartilage elsewhere in the joint, although no evidence in support of such a phenomenon was obtained in Experiment 2. An alternative, and at present more attractive, explanation is suggested by the concept of elasto-hydrodynamic joint lubrication recently developed by Dintenfass (1963). This concept holds that efficient joint lubrication depends not only on suitable properties of the synovial fluid but also on the resiliency and elasticity of the articular cartilage. On this hypothesis injury to one articular surface in a joint would be expected to interfere with joint lubrication and in turn to cause a disturbance in the opposing articular cartilage, which might well be reflected in altered metabolism of its sulphated ground substance.

It is of particular interest that in the rabbit altered sulphate metabolism has been observed usually in the absence of actual fibrillation of the cartilage surface, although there was often a slight reduction in the number of nuclei in the superficial zone. This finding suggests that further attempts should be made to determine if any changes precede the onset of superficial fibrillation in osteo-arthritic human cartilage.

\section{Summary and Conclusions}

Radioactive sulphate has been used to study the metabolism of ground substance in femoral articular cartilage after various operations on the rabbit knee joint. The operative procedures selected did not involve direct surgical trauma to the femoral articular surface. The experiments were performed on adult rabbits of mixed laboratory stock weighing 2 to 3 kg. Animals developing patellar dislocation or showing evidence of joint cavity infection were excluded in analysing the results. The results are based on quantitative radiochemical observations in eighty rabbits. Sulphate metabolism in femoral cartilage from the operated joint was compared with that in its control sample from the contralateral unoperated knee.

It was found that increased cellular utilization of sulphate can be locally induced in an articular cartilage by various surgical procedures not directly injuring its articular surface. Such an effect occurred most frequently when the operative procedure included injury to the opposing articular surface in the same joint (16 out of 21 rabbits), but it sometimes also followed the insertion of a small piece of cartilage or chemically inert plastic into the joint cavity (13 out of 34 rabbits) and it occasionally followed merely opening the joint capsule and then suturing it after manipulating the patella (5 out of 19 rabbits).

As a corollary to these observations, it was found that articular cartilage previously labelled with radioactive sulphate tended to show increased sulphate loss in vivo after insertion of a small piece of cartilage into the joint cavity (4 out of 6 rabbits).

It is concluded that a change in the local environment of an articular cartilage can sometimes increase its turnover of sulphated ground substance.

Altered sulphate metabolism was observed at a time after operation when the femoral articular cartilage usually showed no evidence of fibrillation, although there was often a slight reduction in the number of nuclei in its superficial zone.

I am indebted to Prof. D. H. Collins for his advice and encouragement; to Mr. W. T. Baker and Mr. O. Illman for provision of facilities; to Mrs. Pauline Glossop and Mrs. Sandra Williams for technical assistance; and to Mr. Leslie Platts for his help with the photomicrographs. Much of the expenses of this work were defrayed by a grant to Prof. Collins from the Arthritis and Rheumatism Council.

\section{REFERENCES}

Anderson, C. E. (1962). J. Bone Jt Surg., 44A, 777.

Boström, H., and Månsson, B. (1953). Arkiv. Kemi., 6, 23.

Boyd, E. S., and Neuman, W. F. (1954). Arch. Biochem. Biophys., 51, 475.

Carlson, H. (1957). Acta orthop. scand., Suppl. 28.

Collins, D. H., and McElligott, T. F. (1960). Ann. rheum. Dis., 19, 318.

- and Meachim, G. (1961). Ibid., 20, 117.

Curtiss, P. H., and Klein, L. (1963). J. Bone Jt Surg., 45A, 797.

Dintenfass, L. (1963). Ibid., 45A, 1241.

Gross, J. I., Mathews, M. B., and Dorfman, A. (1960). J. biol. Chem., 235, 2889.

Lack, C. H. (1961). Ann. phys. Med., 6, 93. 
McElligott, T. F., and Collins, D. H. (1960). Ann. rheum. Dis., 19, 31. and Potter, J. L. (1960). J.exp. Med., 112, 743.

Matthews, B. F. (1953). Brit. med. J., 2, 660.

Meachim, G. (1963). J. Bone Jt Surg., 45B, 150.

Le métabolisme du sulfate du cartilage articulaire après l'intervention chirurgicale sur l'articulation

\section{RÉSUMÉ}

On employa le sulfate radioactif pour étudier le métabolisme de la matrice du cartilage fémoral après de différentes opérations su l'articulation du genou de lapin. On choisit des procédés qui n'impliquaient pas de traumatisme chirurgical direct à la surface articulaire fémorale. Les expériences furent effectuées sur des lapins adultes d'un stock de laboratoire mixte, pesant de 2 à $3 \mathrm{~kg}$. Les animaux qui développaient une luxation patellaire ou qui montraient des signes d'infection de la cavité articulaire furent exclus de l'analyse des résultats. Les résultats furent basés sur des observations radiochimiques quantitatives de 80 lapins. On compara le métabolisme du sulfate dans le cartilage fémoral de l'articulation opérée avec celui d'un autre genou contralatéral inopéré.

On trouva que l'utilisation cellulaire augmentée du sulfate peut être induite localement dans un cartilage articulaire par de différents procédés chirurgicaux qui ne produisent pas de lésion directe de la surface articulaire. Cet effet survenait le plus souvent lorsque le procédé opératoire comprenait une lésion de la surface articulaire apposante (16 lapins sur 21), mais il se produisait aussi quand on plaçait dans la cavité articulaire une petite pièce de cartilage ou de plastic chimiquement inerte (13 lapins sur 34) et, quelquefois, quand on ouvrait et suturait simplement la capsule articulaire, après avoir manipulé la rotule (5 lapins sur 19).

Comme corollaire à ces observations, on trouva que le cartilage articulaire marqué préalablement au sulfate radioactif tendait à perdre de plus en plus de son sulfate in vivo après l'insertion d'une petite pièce de cartilage dans la cavité articulaire (4 lapins sur 6).

On conclut qu'un changement du milieu local du cartilage articulaire peut quelquefois y augmenter la circulation de la matrice sulfatée.

Le métabolisme sulfaté altéré fut observé après l'opération alors que le cartilage articulaire fémoral ne montrait pas, habituellement, de signes de fibrillation, bien qu'il y eût souvent une légère réduction du nombre des noyaux dans la zone superficielle.

El metabolismo del sulfato del cartílago articular después de la intervención quirúrgica sobre la articulación

\section{SUMARIO}

Se empleó el sulfato radioactif para estudiar el metabolismo de la matriz del cartílago femoral después de varias operaciones sobre la articulación de la rodilla del conejo. Se escogieron procedimientos que no envolvían traumatismo quirúrgico directo a la superficie articular femoral. Se hicieron los experimentos sobre conejos adultos de un stock de laboratorio mixto, de un peso de 2 a $3 \mathrm{~kg}$. Los animales que desarrollaban luxación patellar o evidenciaban infección de la cavidad articular fueron excluidos del análisis de los resultados. Los resultados se basaron en observaciones radioquímicas cantitativas de 80 conejos. Se comparó el metabolismo del sulfato en el cartílago femoral de la articulación operada con él de una rodilla contralateral inoperada.

Se halló que la utilización celular aumentada de sulfato puede inducirse localmente en un cartílago articular por diferentes procedimientos quirúrgicos que no lesionan directamente la superficie articular. Este efecto ocurre lo más a menudo cuando el procedimiento operativo comprende una lesión de la superficie articular yuxtapuesta (16 de 21 conejos), pero tiene lugar también quando se pone en la cavidad articular un trocito de cartílago o de plástico químicamente inerte ( 13 de 34 conejos) $\mathrm{y}$, a veces, después de abrir y suturar tan solo la cápsula articular, habiendo anteriormente manipulado la rótula (5 de 19 conejos).

Como corolario de estas observaciones, se vió que el cartílago articular previamente marcado con sulfato radioactivo tendía a perderle in vivo después de insertar un trocito de cartílago en la cavidad articular (4 de 6 conejos).

Se concluye que un cambio local del medio ambiente del cartílago articular puede a veces aumentar el intercambio de la matriz sulfatada.

El metabolismo alterado del sulfato fue observado algun tiempo después de la operación cuando el cartílago articular femoral no solía evidenciar fibrillación, aunque a menudo se viera una reducción en el número de los núcleos en su zona superficial. 